\title{
Relationship between access to ICT and the use of electronic library resources by scholars and postgraduate students in a rural-based South African university
}

\author{
Alugumi Samuel Ndou ${ }^{1}$ \\ alugumi.ndou@univen.ac.za ORCID: 0000-0002-8478-9461
}

\begin{abstract}
Received: 2 February 2021
Accepted: 14 May 2021

This study examined access to information and communication technologies (ICTs) and use of electronic library resources (ELRs) in a rural university, against the backdrop of ongoing changes in the way people access information. It aimed to investigate access to ICTs and use of ELRs at the University of Venda (UNIVEN) in South Africa. A quantitative research approach with a survey research design was adopted to collect data. Stratified sampling techniques were employed to select the sample consisting of fortyfive scholars and 150 postgraduate students. The findings revealed that UNIVEN scholars and postgraduate students have access to the prerequisite infrastructure and technology for accessing ELRs. Likewise, the study found that scholars and postgraduate students at UNIVEN have regular access to the internet. The study recommends that UNIVEN library provides research commons for scholars and postgraduate students within the library building.
\end{abstract}

Keywords: Electronic library resources, information and communication technologies, postgraduate students, scholars, South Africa, University of Venda.

\section{Introduction and background}

The use of information and communications technologies (ICTs) for academic purposes in institutions of higher learning requires serious consideration (Ostrowick 2018). ICT refers to any device or system that allows for the electronic storage, retrieval, manipulation or transmission of information (Bwalya \& Mkulama 2017, Zuppo 2012). Personal computers, the internet, and email are some examples of ICTs. ICTs are important in the provision of efficient and up-to-date information services. The rapidly increasing use of ICTs elicits different feelings among information users. This study assumed that some users are overwhelmed by the changes that ICTs have introduced to the process of accessing information. With the introduction of ICTs, libraries now offer various types of technology, such as computers and internet services, to their users (Agyekum, Arthur \& Trivedi 2016).

Investigating internet accessibility and availability within the University of Venda (UNIVEN) campus was important because of the location of the university. Although South Africa's ICT infrastructure is at an advanced level, UNIVEN is located in one of the rural areas of South Africa that are characterised by low penetration of the internet and other ICT services (Dalvit, Kromberg \& Miya 2014). It has been reported that South African rural areas have a lack of computers with internet access and that the cost of internet access is high (Ramavhona \& Mokwena 2016). With UNIVEN being a historically disadvantaged university, it was necessary to understand how the institution is currently faring in terms of internet accessibility and other ICTs, which are essential for both scholars and students to make full use of the available electronic library resources (ELRs). Wangenge-Ouma (2010) noted that the democratic South African government has provided previously disadvantaged universities with more funds to improve their infrastructure.

ELRs in libraries provide access to information for everyone in modern society (Shahapurmath, Medar \& Kenchakkanavar 2015). Moreover, they have the "efficiency and capability in providing [the] right information to the right person at the right time" (Bhat \& Mudhol 2014: 28). According to Mawere \& Sai (2018), ELRs are important in teaching as well as in learning. Furthermore, as Ani, Ngulube and Onyancha (2015: 5) pointed out, ELRs provide "platforms for information to aid in research conducted by academic staff".

UNIVEN is situated in Vhembe, one of the rural districts in the Limpopo province of South Africa. It was established as a campus of the University of Limpopo, formerly known as the University of the North, on 18 February 1981 (University of Venda [UNIVEN] 2012). Like other historically disadvantaged universities in SA, it was established to serve the black population, in its case, Tshivenda speakers in particular (Edwards 2015). Under the new political dispensation in 1997, it was mandated to be a comprehensive university that offers career, academic and vocationally focused programmes that

1. Alugumi Samuel Ndou is Information Literacy Librarian, Library Services Department, University of Venda, South Africa 
address rural development and poverty alleviation (Nkomo \& Sehoole 2007). Due to its location and historical background, UNIVEN is categorised as a rural university that offers both theory- and practice-oriented courses (Nkomo \& Sehoole 2007). Edwards (2015) defined rural universities in the South African context as universities established by the apartheid government to serve ethnic groups such as Sotho, Tswana, Venda, Xhosa, and Zulu.

Williams, Pitchforth and O'Callaghan (2010) stated that students in African countries are discouraged from using ELRs due to poor download speeds. Furthermore, as Statistics South Africa (2018) revealed, internet access in South African rural areas is $45 \%$ compared to $63.7 \%$ in urban areas. However, Madzhie (2010) highlighted that staff and students at UNIVEN obtain information from the internet as they are computer literate and that most students find the internet to be a reliable source of information. Maiwashe (2009), Madzhie (2010) and Nemalili (2014) concur that the UNIVEN community has access to the internet. However, Pearce (1996) and Maiwashe (2009) indicated a lack of adequate ICT infrastructure at UNIVEN.

\section{Problem statement, aim and objectives of the study}

Wordofa (2014) articulated significant growth in access to the internet at top African universities though Aparicio (2003) pointed out that access to the internet in African rural areas is not as good as in African urban areas. In South Africa, there are rural- and urban-based universities. Most South African rural-based universities are historically disadvantaged universities. Institutions categorised as historically disadvantaged were formerly generally under-resourced in various respects, including ICT infrastructure. Even though the current South African government provides these previously disadvantaged universities with more funds to improve their infrastructure, including funds for purchasing of and subscription to ELRs, it is often assumed that there is a lack of ELRs in rural-based universities. As UNIVEN is a previously disadvantaged rural-based institutions, the central research question is therefore the following: is there a positive relationship between access to ICT and the use of ELRs by scholars and postgraduate students in a rural-based South African university? This central research question is subdivided into the following specific research questions:

- Do scholars and postgraduate students in a rural-based South African university have access to ICTs required to use the internet and ELRs?

- Where do scholars and postgraduate students in a rural-based South African university prefer to access the internet and ELRs?

- Do scholars and postgraduate students in a rural-based South African university access ELRs provided by the library?

\section{Literature review}

ICT usage in academic libraries is often under investigation. It is of interest to find that universities do not provide enough ICT in their libraries - as suggested by Manda (2008) that academic libraries in Tanzania had inadequate computers available for scholars and students compared to computers available at other locations within their institutions. To access and use ELRs effectively and efficiently, users need to have access to the internet (Shija 2009). Libraries thus use the internet as a gateway for accessing ELRs. In disadvantaged rural settings, unavailability of computers and internet connectivity could lead to low usage of ELRs (Dulle 2015). Therefore, to provide access to ELRs, an academic institution needs to have a well-structured digital infrastructure for its community. As depicted by Globalization 101 (n.d), overall advancement in information technology and reduced cost of internet access improve internet accessibility. An academic library is responsible for providing academic information to the university community; therefore, it is of importance for the university to ensure that its library is fully equipped with ICTs and ELRs.

Worldwide, there is a growing interest in the use of ELRs among scholars and students (Sohail \& Ahmad 2017). Academic libraries are subscribing to ELRs, such as electronic books (e-books), electronic journals (e-journals), electronic theses and online databases, to enable scholars, researchers, and students to have access to information required for academic purposes. Bhukuvhani, Chiparausha and Zuvalinyenga (2012) stated that more than $80 \%$ of scholars rely on the internet for their research papers. Wema and Manda (2011) showed that the use of ELRs varies greatly between institutions and individuals. Nkosi, Leach and Hoskins (2012) found that supervisors expect students to know how to access and use ELRs. Falc (2013) noted that students prefer ELRs to print resources because they are more affordable; those who do not prefer ELRs indicated that it is because they are harder to read on a screen. Treptow and James (2011) surveyed the use of ELRs by prominent South African scholars and the study revealed that scholars do indeed access ELRs. Similarly, Malapela and De Jager (2015) indicated that scholars in the Faculty of Agriculture at the University of Zimbabwe accessed and used ELRs. The reviewed literature shows that, nowadays, information users are more reliant on ICTs for accessing information. There is a need for an academic library to be well equipped with ICT infrastructure and for it to have relevant ELRs available for the community it serves. 


\section{Methodology}

The study adopted a quantitative research approach and a case study with a survey research design. Self-administered questionnaires were used to collect data from both scholars and postgraduate students. The questionnaire comprised three sections. Section A dealt with demographic variables such as age, academic position and study level; Section B investigated respondents' access to the internet and other ELRs with questions on preferred location of accessing ELRs and internet connectivity; Section C contained questions on respondents' access to ELRs provided by the library. The target population of this study was 375 academics and 1,262 postgraduate students at UNIVEN. A total of 195 questionnaires were personally distributed using a stratified random sampling technique. The questionnaires were distributed to four strata of scholars composed of ten professors, twelve senior lecturers, nineteen lecturers and four junior lecturers. Postgraduate students' four strata consisted of twenty-two doctoral, fifty-four master's, fifty-seven honours, and seventeen postgraduate diploma students. All 195 questionnaires were completed and collected for data analysis: forty-five from scholars and 150 from postgraduate students.

\section{Findings and discussion of the study}

The findings and discussion of the study are organised according to the background information of the respondents; access to the internet and other ICTs; preferred location of access to the internet and ELRs; internet connectivity; access to the library website; and access to ELRs provided by the library.

\subsection{Background information of the respondents}

The data in Table 1 show that the majority $106(72 \%)$ of the postgraduate students were aged between 21 and 30 years, whereas most (twelve; 27\%) scholars were aged between 31 and 40 years. It is noted that most (nineteen; $42 \%$ ) of the scholars who responded were in lectureship positions while the fewest (four; $9 \%$ ) were in junior lectureship positions.

Table 1 Demographic information

\begin{tabular}{lcc}
\hline \multicolumn{1}{c}{ Variable } & Respondents & Frequency \\
\hline Scholars (N=45) & & \\
& $21-30$ years & $8(18 \%)$ \\
& $31-40$ years & $12(27 \%)$ \\
Age & $41-50$ years & $11(24 \%)$ \\
& $51-60$ years & $10(22 \%)$ \\
& 61 and above & $4(9 \%)$ \\
\hline \multirow{3}{*}{ Academic } & Junior lecturers & $4(9 \%)$ \\
position & Lecturers & $19(42 \%)$ \\
& Senior lecturers & $12(27 \%)$ \\
\hline Postgraduate students (N=150) & Professors & $10(22 \%)$ \\
& & \\
& $21-30$ years & $106(71 \%)$ \\
Age & $31-40$ years & $30(20 \%)$ \\
& $41-50$ years & $10(7 \%)$ \\
& $51-60$ years & 1 \\
& 61 and above & 1 \\
\hline \multirow{4}{*}{ Level of study } & Honours & $57(38 \%)$ \\
& Masters & $54(36 \%)$ \\
& Doctoral & $22(15 \%)$ \\
& Postgraduate Diploma in Education & $8(5 \%)$ \\
& Postgraduate Diploma & $7(5 \%)$ \\
& not specified & $4(3 \%)$ \\
\hline
\end{tabular}

\subsection{Access to the internet and other ICTs}

Figure 1 represents regular access to the internet by both scholars and postgraduate students and shows that the majority of scholars $(43 ; 96 \%)$ and postgraduate students $(122 ; 82 \%)$ indicated that they had regular access to the internet. This concurs with findings by Emeka and Nyeche (2016) that the rate of access to the internet by African students is progressing. Only two $(4 \%)$ scholars and twenty-eight (18\%) postgraduate students responded that they had no regular access to the internet. 


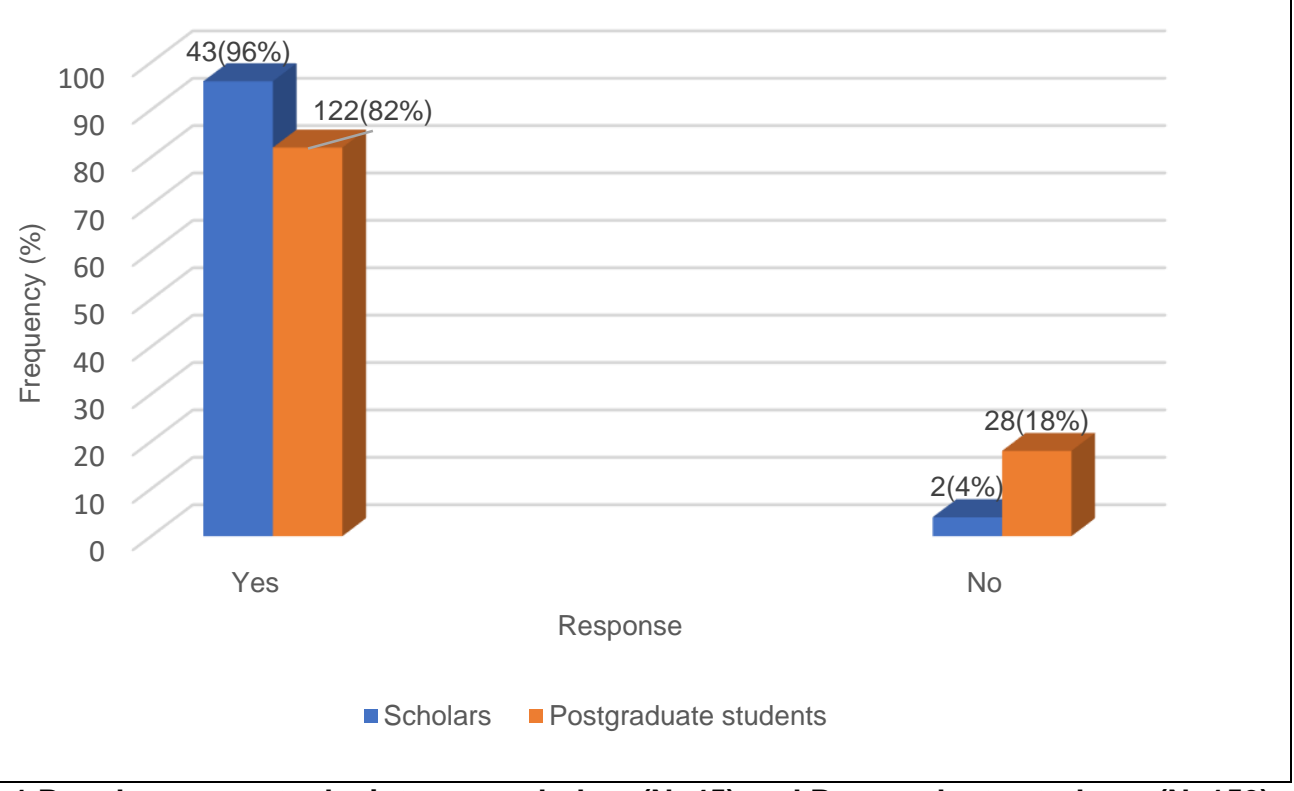

Figure 1 Regular access to the internet: scholars $(\mathrm{N}=45)$ and Postgraduate students $(\mathrm{N}=150)$

This study noted a significant increase in internet accessibility at UNIVEN compared to Pearce (1996) who indicated that there was poor internet accessibility at UNIVEN and Maiwashe (2009), who reported that more than $60 \%$ of students at UNIVEN did not have regular access to the internet. Having regular access to the internet allows scholars and students at UNIVEN to complete academic tasks on time as suggested by Moate, Chukwuere and Mavhungu (2017). Possible reasons for the increase are an increase in the number of computers purchased by the university; the introduction of hotspot internet connectivity (Wi-Fi); and increased bandwidth. These improvements show that previously disadvantaged and ruralbased universities in South Africa are catching up with urban universities in terms of internet accessibility. Mgobozi and Ocholla (2002) articulated that there was not much difference between internet access for students in a rural-based university and an urban university. The findings of this study confirmed the research of Wordofa (2014) which indicated that internet usage in Africa has shown significant growth. With the significant growth in access to the internet, as noted in this study, it is possible for a rural-based university to provide full internet connection to its community soon. With improved internet access in Africa, scholars and students will be able to access ELRs both on and off campus, anywhere and at any time. The improvement in internet access could lead to increased research output from African scholars and researchers.

A chi-square test was conducted using the Statistical Package for Social Sciences (SPSS) to test the access to the internet of scholars and postgraduate students. The chi-square test resulted in a p-value of 0.024 , which is less than 0.05 , which shows a significant association between being a scholar or a postgraduate student and having regular access to the internet. Scholars have more regular access to the internet than postgraduate students. This difference might be caused by economic factors, such as scholars' ability to purchase or subscribe to data bundles to access the internet, and their having more time to access the internet while in their offices. Other studies have noted that economic factors had an influence on access to and use of the internet. Naude, Rensleigh and du Toit (2005) noted that demographic characteristics influenced internet usage among scholars at the University of South Africa. Sarasvady and Khatri (2007) also argued that variables, such as demographic characteristics, have an influence on internet access. Dukić and Strišković (2015) named academic level and field of study as some of the variables affecting access to and use of ELRs.

\subsection{Preferred location of access to the internet and ELRs}

Table 2 shows that the majority $(43 ; 65 \%)$ of the scholars accessed the internet from their offices, twenty $(30 \%)$ from home and three (5\%) at the library. The preferred location for accessing the internet reported by scholars in this study is the same as what has been reported in other studies (Hadagali \& Kumbar 2011, Jayaprakash 2017, Korobili, Tilikidou \& Delistavrou 2006) where it was found that more scholars access ELRs from their offices than in libraries. Lack of special computer areas in the library and greater comfort in their offices might be why scholars are not using library computers. In 2011, UNIVEN library had 237 personal computers (PCs) with access to the internet and ELRs for the university community to use (UNIVEN 2013). The number of available PCs might mean that scholars and postgraduate students have to share PCs while in the library.

Ninety-nine (42\%) postgraduate students access the internet from library computers, forty-one (18\%) from the departmental computer laboratory, thirty-seven (16\%) from a general computer laboratory, thirty-three (14\%) from home 
and twenty-three (10\%) from other locations. This study has therefore found that postgraduate students prefer to access the internet from the library than from other locations. The studies of Chandran (2013), Mittal and Bala (2013) and Kumar (2016) also revealed that most of the students accessed the internet from the library. This study seems to concur with the findings by Twill (2012) that people from disadvantaged rural communities rely on libraries for internet access. The Bill and Melinda Gates Foundation (2007 in Twill 2012) reported that most people from low-income and disadvantaged households use libraries to access the internet and other ELRs. UNIVEN is a rural-based university; consequently, some of its students may come from low-income and disadvantaged households and may not be able to afford their own computers and data bundles to access the internet from home.

Table 2 Location of accessing the internet by scholars and postgraduate students

\begin{tabular}{lc}
\hline Responses & Frequency \\
\hline Scholars (N=45) & \\
Home & $20(30 \%)$ \\
Library & $3(5 \%)$ \\
Office & $43(65 \%)$ \\
Total & $\mathbf{6 6}$ \\
\hline Postgraduate students (N=150) & \\
Library computers & $99(42 \%)$ \\
Departmental computer laboratory & $41(18 \%)$ \\
General computer laboratory & $37(16 \%)$ \\
Home & $33(14 \%)$ \\
Others & $23(10 \%)$ \\
Total & $\mathbf{2 3 3}$ \\
\hline
\end{tabular}

\subsection{Internet connectivity}

In Table 3, the data show that the majority of scholars (forty; 60\%) use cabled internet. Fifteen (22\%) scholars used university $\mathrm{Wi}-\mathrm{Fi}$, eleven (16\%) used a cellular connection and one used a modem connection. With regard to internet connectivity, this study notes that not all scholars had network cables in their offices. Some scholars used other types of internet connectivity, such as Wi-Fi and mobile phones, in their offices. Furthermore, this study reveals that the recommendation by Madzhie (2010) - that UNIVEN should allocate wireless hotspot areas for the university community as there was, at the time, no Wi-Fi connectivity - has been implemented. Data from Table 3 also show that 102 (49\%) postgraduate students use Wi-Fi connectivity while on campus, seventy-eight (38\%) used cabled internet and twenty-seven (13\%) used a cellular connection. Moate, Chukwuere and Mavhungu (2017) indicated that students welcome the introduction of Wi-Fi and view it as essential to their academic tasks. This study concurs that the available Wi-Fi connection is useful to both scholars and postgraduate students. Noticeably, only one academic and one postgraduate student indicated use of another mode of connectivity such as a modem. This study shows that most of UNIVEN's scholars and postgraduate students rely on the university for an internet connection while on campus.

Table 3 Internet connectivity

\begin{tabular}{lc}
\hline Responses & Frequency \\
\hline Scholars' internet connectivity: on campus (N=45) \\
Cable & $40(60 \%)$ \\
UNIVEN Wi-Fi & $15(22 \%)$ \\
Cellular & $11(16 \%)$ \\
Other (modem) & 1 \\
Total & $\mathbf{6 7}$ \\
\hline Postgraduate students' internet connectivity: on campus (N=150) \\
Cable & $78(38 \%)$ \\
UNIVEN Wi-Fi & $102(49 \%)$ \\
Cellular & $27(13 \%)$ \\
Other (modem) & 1 \\
Total & $\mathbf{2 0 8}$ \\
\hline
\end{tabular}




\subsection{Access to the library website}

The findings of this study are that the library website was fully utilised by both scholars and postgraduate students. Table 5 show that forty-one (92\%) scholars accessed the library website, two (4\%) did not access the library website and two (4\%) are not sure if they have accessed the library website. In addition, Table 5 shows that $132(89 \%)$ postgraduate students access the library website, thirteen (9\%) do not and four (2\%) were not sure if they access it. Kumar and Bansal (2014) articulated that a library website helps in building a long-term relationship with patrons. While perceived ease of use, or usefulness, of the website might be the cause for full utilisation of the university library website, this study did not investigate the factors that influence scholars and postgraduate students to access the library website.

Table 5: Scholars and postgraduate students who access the library website

\begin{tabular}{lc}
\hline Responses & Frequency \\
\hline Scholars (N=45) & \\
Yes & $41(92 \%)$ \\
No & $2(4 \%)$ \\
Not sure & $2(4 \%)$ \\
Total & $\mathbf{4 5}$ \\
\hline Postgraduate students (N=149) & \\
Yes & $132(89 \%)$ \\
No & $13(9 \%)$ \\
Not sure & $4(2 \%)$ \\
Total & $\mathbf{1 4 9}$ \\
\hline
\end{tabular}

\subsection{Access to ELRs provided by the library}

Figure 2 shows that twenty-nine (64\%) scholars accessed the ELRs provided by the library sometimes, fourteen (32\%) often and two (4\%) were not sure. Among postgraduate students, sixty-seven (45\%) accessed the ELRs provided by the library sometimes, followed by fifty-six $(38 \%)$ who did so often and twenty $(13 \%)$ never, while six $(4 \%)$ said they were not sure. There is thus evidence that scholars at UNIVEN are fully aware of the available ELRs. However, twenty (13\%) of the postgraduate students indicated that they had never accessed ELRs provided by the university. Hadagali and Kumbar (2011) noted that scholars at Karnataka State accessed ELRs provided by the university library. Likewise, Sonkar, Singh and Kumar (2014) noted access and use of ELRs by scholars and postgraduate students at Banaras Hindu University. This study revealed a significant association in frequency of access to ELRs with being a scholar or a postgraduate student. The chi-square test conducted revealed less than a 0.05 p-value in frequency of access to ELRs by scholars and postgraduate students, meaning that scholars accessed ELRs more frequently than postgraduate students. This might be caused by scholars having more opportunities to access the internet or they might have used their own financial resources to access the internet while off-campus. Conducted chi-square test revealed $0.028 p$-value in frequency of access to ELRs by scholars and postgraduate students, meaning that there is a significant relationship in the access of ELRs by scholars and postgraduate students. A p-value which is less than 0.05 indicates a significant correlation between variables.

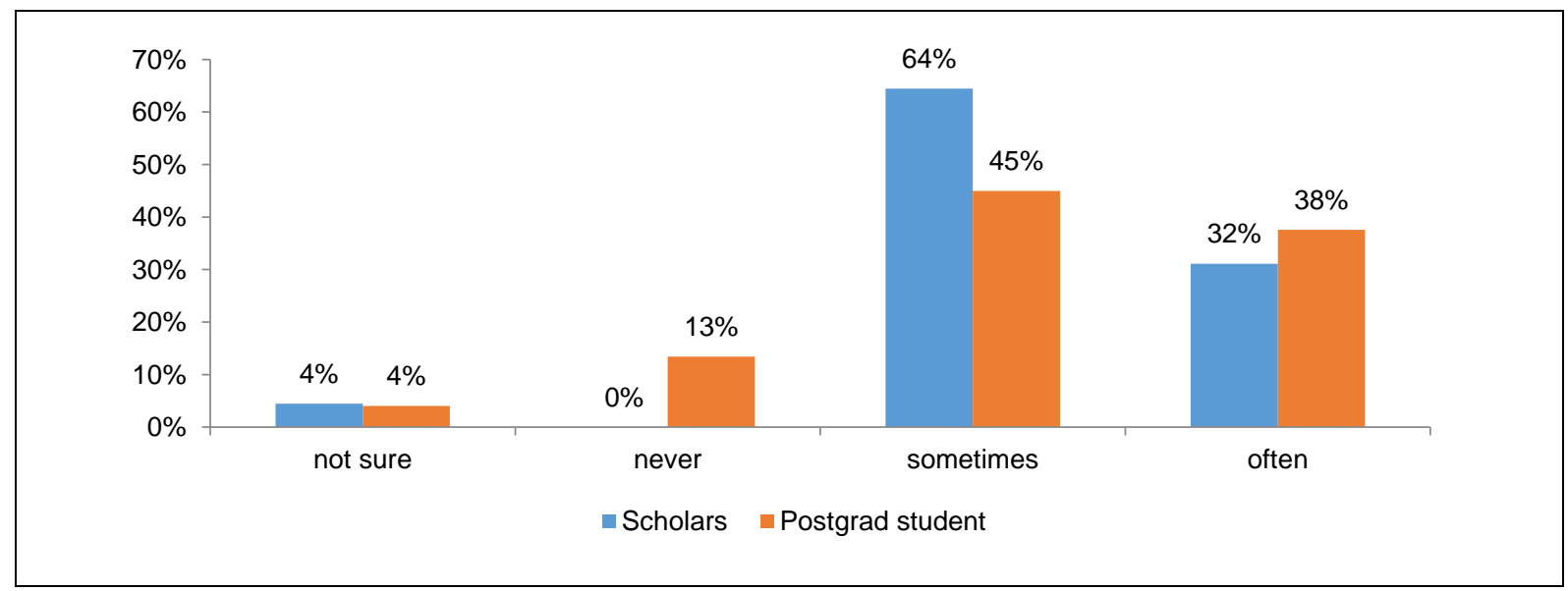

Figure 2 Access to ELRs provided by the library: scholars $(\mathrm{N}=45)$ and postgraduate students $(\mathrm{N}=150)$ 


\section{Conclusion and recommendations}

This study used a quantitative research approach and case study with a survey research design to investigate access to ICTs and the use of ELRs in one of the rural-based universities in SA, UNIVEN. This study concludes that UNIVEN has the prerequisite technologies and facilities necessary for adequate utilisation of ELRs. This study also concludes that access to ICTs and use of ELRs at a rural-based university are the same as in other universities. From the chi-square test results, the study concluded that scholars have more regular access to the internet than postgraduate students, possibly because of economic factors, such as the ability to purchase or subscribe to data bundles to access the internet, and scholars having more time to access the internet while in their offices. Furthermore, this study concludes that the library website was utilised by both scholars and postgraduate students. This suggests that the library website could be a useful tool to inform the scholars and students of the available ELRs and library services. This study recommends that the library provide a research commons area equipped with ICT facilities for the exclusive use of scholars, master's and doctoral students. Further investigation on undergraduate students' access to and use of ELRs at a rural-based university is required. This study also recommends an investigation to establish whether there is a significant relationship between regular internet access of scholars and of students in rural-based and urban universities. It is understandable that there is a need for equal opportunities to access information for scholars and students both in rural and in urban areas.

\section{References}

Agyekum, B.O., Arthur, B. and Trivedi, M. 2016. Adoption of social networking tools in public university libraries in Ghana. International Journal of Innovative Research and Development. 5(5): 158-168. [Online]. http://www.internationaljournalcorner.com/index.php/ijird_ojs/article/view/136393/95517 (26 April 2018).

Ani, O.E., Ngulube, P. and Onyancha, B. 2015. Perceived effect of accessibility and utilization of electronic information resources on productivity of academic staff in selected Nigerian universities. SAGE Open: 5(4): 1-7. DOI:10.1177/2158244015607582.

Aparicio, M.A.M. 2003. Access to the electronic publishing in African countries: some reflections. From information to knowledge: Proceedings of the 7th ICCC/IFIP International Conference on Electronic Publishing. 25-28 June 2003. Minho, Portugal: Universidade do Minho. [Online]. https://core.ac.uk/download/pdf/47275619.pdf (20 July 2016).

Bhat, I. and Mudhol, M.V. 2014. Use of e-resources by faculty members and students of Sher-E-Kashmir Institute of Medical Science (SKIMS). DESIDOC Journal of Library and Information Technology, 34(1): 28-34. [Online]. http://publications.drdo.gov.in/ojs/index.php/dj/it/article/view/5943/3080. (17 February 2016).

Bhukuvhani, C., Chiparausha, B. and Zuvalinyenga, D. 2012. Effects of electronic information resources skills training for lecturers on pedagogical practices and research productivity. International Journal of Education and Development using Information and Communication Technology, 8(1): 16-28. [Online]. http://ijedict.dec. uwi.edu/include/getdoc.php?id=5066\&article=1383\&mode=pdf (15 March 2016).

Bwalya, T. and Mkulama, A. 2017. The use of free and open source software (FOSS) in Zambia: a case study of government departments. The International Journal of Multi-Disciplinary Research. [Online]. http://www.multiresearch.net/cms/publications/CFP1852017.pdf (26 April 2017).

Chandran, V. 2013. Use and user perception of electronic information resources: a case study of Siva Institute of Frontier Technology, India. Chinese Librarianship: An International Electronic Journal, 36. [Online]. http://www.whiteclouds.com/iclc/cliej/cl36chandran.pdf (01 March 2016).

Czerniewicz, L. and Brown, C. 2014. The habitus and technological practices of rural students: a case study. South African Journal of Education, 34(1): 1-14. DOI:10.15700/201412120933.

Dalvit, L., Kromberg, S. and Miya, M. 2014. The data divide in a South African rural community: a survey of mobile phone use in Keiskammahoek. Proceedings of the e-Skills for Knowledge Production and Innovation Conference. 17-21 November 2014. Cape Town, South Africa. Santa Rosa, California : Informing Science Institute. 87-100. [Online]. http://proceedings.e-skillsconference.org/2014/e-skills087-100Dalvit842.pdf (27 September 2017).

Dukić, D. and Strišković, J. 2015. Croatian university students' use and perception of electronic resources. Library and Information Science Research, 37(3): 244-253. DOI:10.1016/j.lisr.2015.04.004.

Dulle, F.W. 2015. Online information resources availability and accessibility: a developing countries' scenario. African Journal of Library, Archive and Information Science, 25(1): 45-57.

Edwards, S.D. 2015. The role of rural universities in developing psychology in South Africa. South African Journal of Psychology, 45(1): 50-59. DOI:10.1177/0081246314555305.

Emeka, U.J. and Nyeche, O.S. 2016. Impact of internet usage on the academic performance of undergraduate students: a case study of the University of Abuja, Nigeria. International Journal of Scientific \& Engineering Research, 7(10): 1018-1028. [Online]. https://www.ijser.org/researchpaper/Impact-of-Internet-Usage-on-the-Academic-Performanceof-Undergraduates-Students--A-case-study-of-the-University-of-Abuja--Nigeria.pdf (05 May 2018).

Falc, E.O. 2013. An assessment of college students' attitudes towards using an online e-textbook. Interdisciplinary Journal of E-learning and Learning Objects, 9: 1-12. [Online]. http://www.ijello.org/Volume9/IJELLOv9p001012Falc831.pdf (15 March 2016).

Globalization 101. n.d. Technology and globalization. [Online]. https://www.globalization101.org/uploads/File/Technology/tech.pdf (27 September 2017). 
Hadagali, G.S. and Kumbar, B.D. 2011. Use of internet by faculty members and research scholars in the $21^{\text {st }}$ century: a study of university libraries of Karnataka State, India. Sri Lankan Journal of Librarianship and Information Management, 4(1): 1-17.

Jayaprakash, H. 2017. Internet use pattern among the faculties of D.M's College: a case study. Library Philosophy and Practice (e-journal). 1527. [Online]. https://digitalcommons.unl.edu/libphilprac/1527 (05 May 2018).

Wordofa, K.H. 2014. Adoption of web 2.0 in academic libraries of top African universities. The Electronic Library, 32(2): 262-277.

Korobili, S., Tilikidou, I. and Delistavrou, A. 2006. Factors that influence the use of library resources by faculty members. Library review, 55(2): 91-105. DOI:10.1108/00242530610649594.

Kumar, R. 2016. Use of E-resources by the medical students of M.M. University, Ambala: a case study. DESIDOC Journal of Library and Information Technology, 36(1): 10-16. DOI:10.14429/djlit.36.1.8959.

Kumar, V. and Bansal, J. 2014. Qualities of a library website: evaluating library website of new IITs. International Journal of Information Dissemination and Technology, 4(4): 283-288. [Online]. https://www.ijidt.com/index.php/ijidt/article/view/443/441 (05 May 2018).

Madzhie, C.N. 2010. Challenges facing academic libraries in the management of library user education and information literacy: a case study of University of Venda. Thesis. University of Venda, Thohoyandou.

Maiwashe, R. 2009. Perception of university students on communication channels and access to available sources of information for effective learning. Dissertation. University of Venda, Thohoyandou.

Malapela, T. and De Jager, K. 2015. Using an electronic journal availability study to measure access to electronic journals by scholars and researchers in the faculty of agriculture at the University of Zimbabwe. Library and Information Research, 39(120): 29-42. [Online]. https://www.lirgjournal.org.uk/index.php/lir/article/view/650/690 (24 March 2016).

Manda, P.A. 2008. Access to electronic library resources and services in academic and research institutions in Tanzania. In Evaluating electronic resources programmes and provision: case studies from Africa and Asia. D. Rosenberg, Ed. Oxford: INASP.

Mawere, T. and Sai, K.O.S. 2018. An investigation on e-resource utilisation among university students in a developing country: a case of Great Zimbabwe University. South African Journal of Information Management, 20(1): 1-7. DOI:10.4102/sajim.v20i1.860.

Mgobozi, M.N. and Ocholla, D.N. 2002. The use of electronic journals for the dissemination of scholarly information by the University of Natal and the University of Zululand. South African Journal of Library and Information Science, 68(2): 81-93. DOI:10.7553/68-2-742.

Mittal, P. and Bala, M. 2013. Use of e-resources in universities. International Journal of Innovative Research in Computer and Communication Engineering, 1(6). [Online]. http://ijircce.com/admin/main/storage/app/pdf/C05tWxUdrAWQF5xX7WNncGz7icJ4BIlovMFloDt2.pdf (08 March 2016).

Moate, K.M., Chukwuere, J.E. and Mavhungu, M.B. 2017. The impact of wireless fidelity on students' academic performance in a developing economy. Proceedings of the 31st International Academic Conference. 29-31 May 2017. London. Prague: International Institute of Social and Economic Sciences. 139-155. DOI:10.20472/IAC.2017.031.032.

Naude, F., Rensleigh, C. and du Toit, A.S.A. 2005. Analysis of the citation of Web-based information resources by UNISA academic researchers. South African Journal of Information Management, 7(3). DOI:10.4102/sajim.v7i3.272.

Nemalili, T.V. 2014. An assessment of the effectiveness of the academic library online public access catalogue (OPAC) by students: a case study of University of Venda. Thesis. University of Venda, Thohoyandou.

Nkomo, M. and Sehoole, C. 2007. Rural-based universities in South Africa: albatrosses or potential nodes for sustainable development? International Journal of Sustainability in Higher Education, 8(2): 234-246. DOI:10.1108/14676370710726689.

Nkosi, D., Leach, A. and Hoskins, R. 2012. Academic staff expectations of undergraduate students with respect to their use of the library at the University of KwaZulu-Natal, Pietermaritzburg campus. South African Journal of Library and Information Science, 78(2): 79-87. DOI:10.7553/78-2-111.

Ostrowick, J. 2018. Challenges in introducing ICTs in teaching and learning in South Africa. [Online]. https://www.researchgate.net/publication/324080145 (05 May 2018).

Pearce, R.J. 1996. Assessment of the library and information needs and expectations of University of Venda academic staff. Thesis. University of Venda.

Ramavhona, T.C. and Mokwena, S. 2016. Factors influencing internet banking adoption in South African rural areas. South African Journal of Information Management, 18(2): 1-8. DOI:10.4102/sajim.v18i2.642.

Sarasvady, S. and Khatri, N.K. 2007. Study of the use of electronic resources for implementing library consortium. [Online]. https://www.isical.ac.in/ serial/consortia/CBSOR-07.pdf (01 March 2016).

Shahapurmath, S.D., Medar, A.S. and Kenchakkanavar, AY. 2015. Use of electronic resources by the PG students of Karnatak College, Dharwad: a study. International Journal of Advanced Research in Education and Technology (IJARET) 2(3): 210-212. [Online]. http://ijaret.com/wp-content/themes/felicity/issues/vol2issue3/ver2/sateesh.pdf (17 February 2015).

Shija, H. 2009. E-resources use via the internet improvement is a must: a case of special libraries in Tanzania. Dar es Salaam: REPOA). 
Sohail, M.D. and Ahmad, S. 2017. Use of electronic resources and services by faculty members and students of Fiji National University. DESIDOC Journal of Library and Information Technology, 37 (3): 165-171.

DOI:10.14429/djlit.37.3.10567.

Sonkar, S.K., Singh, M.P. and Kumar, J. 2014. Use of electronic resources by post graduate students and research scholars of the Banaras Hindu University: a study. Journal of Information Management, 1(2): 87-97. [Online]. https://splpjim.org/wp-content/uploads/2016/04/Article-3.pdf (05 May 2018).

Statistics South Africa. 2018. General household survey. [online]. http://www.statssa.gov.za/publications/P0318/P03182018.pdf (16 June 2019).

Treptow, R. and James, M. 2011. Use of online knowledge resources by prominent South African researchers. South African Journal of Library and Information Science, 77(1): 64-74. DOI:10.7553/77-1-67.

Twill, S.E. 2012. Do e-books bridge the digital divide? In No shelf required 2: use and management of electronic books. S. Polanka, Ed. London: Facet Publishing.

University of Venda (UNIVEN). 2012. From inkpot to iPad: towards an educational centre of excellence. Thohoyandou: University of Venda.

UNIVEN. 2013. University of Venda annual report. Thohoyandou: University of Venda. [Online]. http://www.univen.ac.za/docs/UnivenAnnualReport2012_Low.pdf (11 July 2017).

Wangenge-Ouma, G. 2010. Funding and the attainment of transformation goals in South Africa's higher education. Oxford Review of Education, 36(4): 481-497. https://www.jstor.org/stable/25753509.

Wema, E. and Manda, P. 2011. The impact of e-resource usage in academic and research institutions in Tanzania. INASP. [online]. https://www.inasp.info/sites/default/files/2018-04/impact_of_e-resources_in_tanzania.pdf (16 March 2016).

Williams, C.D., Pitchforth, E.L. and O'Callaghan, C. 2010. Computers, the internet and medical education in Africa. Medical Education, 44: 485-488. DOI:10.1111/j.1365-2923.2009.03602.x.

Zuppo, C.M. 2012. Defining ICT in a boundaryless world: the development of a working hierarchy. International Journal of Managing Information Technology, 4(3): 13-22. DOI:10.5121/ijmit.2012.4302. 